\title{
Genetic Studies of the Fertility Plasmid SCP2 and its SCP2* Variants in Streptomyces coelicolor A3(2)
}

\author{
By MERVYN J. BIBB十 AND DAVID A. HOPWOOD* \\ John Innes Institute, Colney Lane, Norwich NR4 7UH, U.K.
}

(Received 27 February 1981)

\begin{abstract}
The plasmid SCP2, initially discovered through the occurrence of a high fertility variant, SCP2*, is a self-transmissible fertility factor capable of promoting chromosomal recombination within Streptomyces coelicolor A3(2). Further high fertility variants of SCP2, similar to SCP2*, were isolated from amongst the recombinants produced in matings involving SCP2, and their genetic properties were compared. SCP2 and its derivatives elicit lethal zygosis on transfer into an SCP2- recipient; this plasmid-determined phenotype allowed the isolation of SCP2- strains and the detection of the interspecific transfer of SCP2* by mating from $S$. coelicolor to Streptomyces parvulus and Streptomyces lividans, whereupon it underwent stable maintenance. The transfer genes of SCP2 and SCP2*, which are not normally fully expressed, were shown to undergo transient derepression on entry into an SCP2- strain. An 'entry disadvantage' system determined by SCP2 and SCP2* was recognized.
\end{abstract}

\section{INTRODUCTION}

Plasmids have been identified in many Streptomyces species and have been implicated in the control of a range of phenotypic properties, including the transfer of chromosomal markers ('fertility'), antibiotic synthesis and resistance, differentiation, and melanin production (Hopwood, 1978; Chater, 1979; Okanishi, 1979; Schrempf \& Goebel, 1979). However, with certain exceptions, genetic evidence for the existence of Streptomyces plasmids has been limited to studies of the effect of plasmid-curing agents on the stability of particular phenotypes, notably antibiotic production (Hopwood, 1979).

SCP1 in Streptomyces coelicolor A3(2) was the first example of a fertility plasmid in this genus (and, indeed, in any Gram-positive bacterium). It was identified (Vivian, 1971) by the infectious transfer of the ability to produce and be resistant to an antibiotic (later characterized as methylenomycin A; Wright \& Hopwood, 1976) amongst derivatives of $S$. coelicolor A3(2), correlated with well-defined effects on the fertility of the organism when SCP1 was present, either in the autonomous or integrated state (Hopwood et al., 1973; Hopwood \& Wright, 1976). SCP1 is difficult to isolate (Hopwood et al., 1979; Westpheling, 1980) and there is little information about its physical structure; therefore, genetic studies of methylenomycin production (Kirby \& Hopwood, 1977) and some other SCP1-determined characters (Kirby, 1976) so far lack the benefit of a complementary physical analysis. In Streptomyces rimosus, a plasmid, SRP1, was implicated in chromosomal fertility when present in the autonomous state but it was not characterized physically (Friend et al., 1978). A transmissible plasmid of Streptomyces reticuli, which is concerned, directly or indirectly, in the control of production of a macrolide antibiotic and of resistance to it, in differentiation,

\footnotetext{
$\dagger$ Present address: Department of Genetics, Stanford University School of Medicine, Stanford University
} Medical Center, Stanford, California 94305, U.S.A. 
and in melanin production has been studied physically (Schrempf \& Goebel, 1979), but its possible role in chromosomal fertility is yet to be defined.

SCP2, the second sex plasmid to be discovered in $S$. coelicolor A3(2), was first identified genetically by the occurrence of a high fertility variant, SCP2*. This, in turn, facilitated the isolation of SCP2 $2^{-}$strains and allowed SCP2 to be equated with a previously studied 'cryptic' plasmid (Schrempf et al., 1975), elsewhere termed pSH1 (Schrempf \& Goebel, 1977). SCP2 and SCP2* exist within the mycelium in low copy number as covalently closed circular (CCC) DNA molecules of length $31 \mathrm{~kb}$ (Bibb et al., 1977; Schrempf \& Goebel, 1977); SCP2 and SCP2* were indistinguishable by restriction enzyme mapping (Bibb et al., 1977). This paper describes genetic studies of SCP 2 and SCP2* which identify and characterize several plasmid-determined properties, some of which appear analogous to those exhibited by well-studied plasmids of Gram-negative bacteria.

\section{METHODS}

Culture conditions and genetic analysis. Minimal (MM) and complete (CM) media and methods of crossing and recombinant analysis were as described by Hopwood (1967) and Hopwood et al. (1973). R2 medium was that of Okanishi et al. (1974).

Bacterial strains. These were derivatives of Streptomyces coelicolor A3(2) (Hopwood et al., 1973), S. lividans 66 (Lomovskaya et al., 1972) and S. parvulus ATCC 12434; they are listed in Table 1. SCP2- derivatives were

Table 1. Streptomyces strains

\begin{tabular}{|c|c|c|c|}
\hline JII stock no. ${ }^{\dagger}$ & Chromosomal genetic markers & Plasmid status: & Origin $\dagger$ \\
\hline $\begin{array}{l}\text { coelicolor A3 } \\
12 \\
104 \\
1098 \\
1190 \\
1516 \\
1705 \\
1865 \\
2278 \\
\text { A } 700 \\
\text { M107 } \\
\text { M108 } \\
\text { M109 } \\
\text { M110 } \\
\text { M111 } \\
\text { M124 } \\
\text { M130 } \\
\text { M132 } \\
\text { M133 } \\
\text { M138 } \\
\text { M146 } \\
\text { M147 } \\
\text { M148 }\end{array}$ & 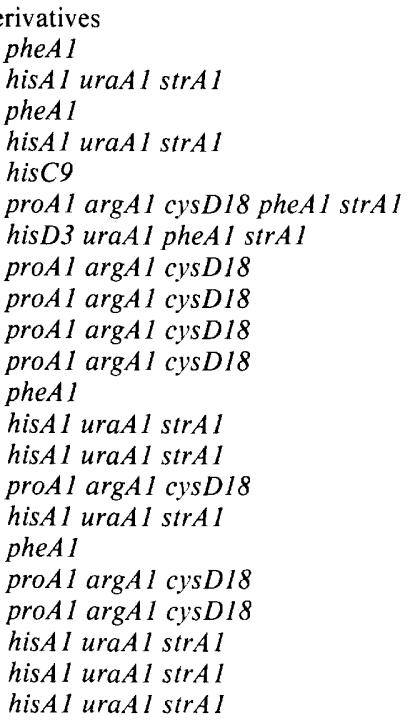 & 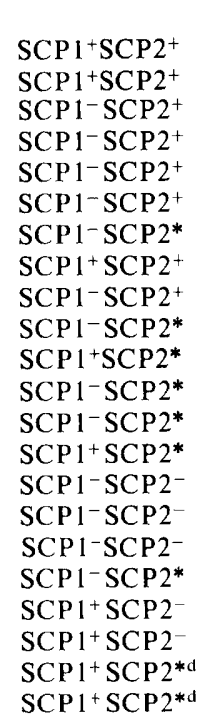 & 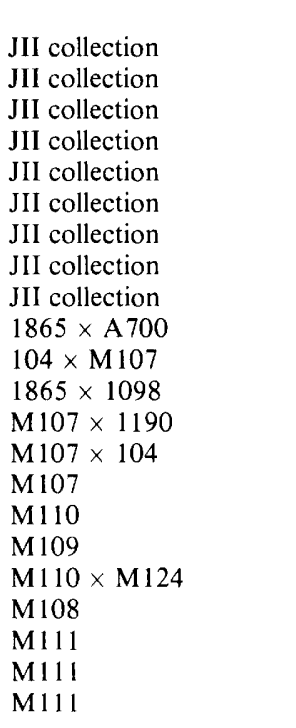 \\
\hline $\begin{array}{l}\text { parvulus ATC } \\
2283 \\
2296 \\
\text { M151 } \\
\text { M155 }\end{array}$ & $\begin{array}{l}2434 \text { derivatives } \\
\text { str-1 } \\
\text { str-1 } \\
\text { str-1 } \\
\text { str-1 }\end{array}$ & $\begin{array}{l}\mathrm{SCP} 1^{-} \mathrm{SCP} 2^{-} \\
\mathrm{SCP} 1^{+} \mathrm{SCP} 1^{-} \\
\mathrm{SCP} 1^{+} \mathrm{SCP} \mathrm{STR}^{*} \\
\mathrm{SCP} 1^{-} \mathrm{SCP} 2^{*}\end{array}$ & $\begin{array}{l}\text { JIl collection } \\
\text { JII collection } \\
\text { M111 × 2296 } \\
\text { M133 × 2283 }\end{array}$ \\
\hline $\begin{array}{l}\text { lividans } 66 \mathrm{~d} \\
1326 \\
\mathrm{M} 245\end{array}$ & $\begin{array}{l}\text { ves } \\
- \\
-\end{array}$ & $\begin{array}{l}\mathrm{SCP} 1^{-} \mathrm{SCP} 2^{-} \\
\mathrm{SCP} 1^{-} \mathrm{SCP} 2^{*}\end{array}$ & $\begin{array}{l}\text { JII collection } \\
\text { Transformation of } 1326\end{array}$ \\
\hline
\end{tabular}

$\dagger \mathrm{JII}$ indicates John Innes Institute; strains prefixed M were derived during the present work.

$\ddagger S C P 2 * d$ represents SCP2* exhibiting reduced fertility properties; SCP2*TR represents SCP2* containing tandemly repeated sequences. 
obtained by screening for the spontaneous loss of the SCP2*-determined fertility or lethal zygosis phenotypes, employing either the plate-crossing technique or by replica-plating to lawns of SCP2- isolates, respectively (Bibb et al., 1977). SCP2* derivatives of different chromosomal genotype, both with and without SCP1, were obtained by transferring one or other of the plasmids, by mating. into appropriate recipient strains. The chromosomal genotype of each of the derivatives was confirmed by replication to test media; the presence of SCP1 was confirmed by the ability of the derivative to produce methylenomycin on $\mathrm{CM}$, which inhibited the development of SCP1- but not $\mathrm{SCP} 1^{+}$strains; the presence of SCP2* was tested by assaying for the ability of the derivative to express the fertility and lethal zygosis phenotypes previously associated with this plasmid, using the plate-crossing or replica-plating techniques, and confirmed by the isolation and restriction endonuclease cleavage analysis of plasmid DNA.

Plasmid isolation and restriction endonuclease cleavage analysis. The methods used were those described by Bibb et al. (1977). Restriction endonucleases were obtained from New England Biolabs and used in accordance with the manufacturer's recommendations.

Testing of sensitivity to heavy metal ions and antibiotics. Solutions of metal salts or antibiotics were added to filter paper discs at concentrations sufficient to cause growth inhibition and the discs were laid on the surface of CM or supplemented MM plates spread with spore suspensions of various $S$. coelicolor strains.

Bacteriocin tests. Cultures were grown for $3 \mathrm{~d}$ on plates of Oxoid nutrient agar with or without the addition of $8 \mathrm{mM}-\mathrm{Ca}\left(\mathrm{NO}_{3}\right)_{2}$. Aqueous extracts were made by freezing and thawing the plates and removing agar and culture debris by low speed centrifugation. Bacteriocin activity was tested by adding $0.3 \mathrm{ml}$ of culture filtrate to wells cut in plates of Oxoid nutrient agar containing $8 \mathrm{~mm}-\mathrm{Ca}\left(\mathrm{NO}_{3}\right)_{2}$ and overlaid with spores of various streptomycetes embedded in Oxoid nutrient agar containing half the normal agar concentration.

Ultraviolet survival curves. These were determined as described by Harold \& Hopwood (1970).

\section{RESULTS}

\section{$S C P 2 *$-determined lethal zygosis}

The property of SCP2*-determined lethal zygosis was first observed on replica-plating SCP2*-containing cultures to confluent lawns of SCP2 ${ }^{-}$(lethal zygosis sensitive, $\mathrm{Ltz}^{\mathrm{s}}$ ) derivatives (Bibb et al., 1977). Lethal zygosis was later found to be elicited from the growth of single spores of an SCP2* strain in a background lawn of an $\mathrm{SCP} 2^{-}$isolate. Serial dilutions of strain M110 (SCP2*) were spread on supplemented MM with and without the addition of sufficient spores of strain M132 (SCP2-) to produce confluent growth. After sporulation, an almost exact correlation was observed between the numbers of colonies of strain M 110 and of small circular areas of lethal zygosis, termed 'pocks', produced in the SCP2- lawns. The pocks had a composite structure: most appeared to be growth-centred, with a series of concentric zones of inhibition and of growth.

SCP2* strains were also found to elicit lethal zygosis in the presence of SCP1, both when patches of strain $\mathrm{M} 108\left(\mathrm{SCP} 1^{+} \mathrm{SCP} 2^{*}\right)$ were replica-plated to lawns of $\mathrm{M} 138\left(\mathrm{SCP}^{+}{ }^{+} \mathrm{SCP} 2^{-}\right)$on $\mathrm{CM}$ and when individual spores of $\mathrm{M} 111$ (SCP $1^{+} \mathrm{SCP} 2^{*}$ ) were allowed to grow in lawns of M138 on CM. The composite nature of the pocks was again clearly apparent (Fig. 1). The finding of the Ltz reaction of SCP2* against SCP2- strains in the presence as well as in the absence of SCP1 provided further evidence for the independent nature of SCP1 and SCP2.

If, as suggested (Bibb et al., 1977), the growth inhibition revealed in the Ltz reaction was associated with the transfer of SCP2* into an SCP2- background, and was not produced by a diffusible inhibitor, then the plasmid ought to be present in each of the zones of the composite pocks, right up to their perimeter. To test this hypothesis, spores and mycelial fragments from each of the concentric zones, including the centre of the pock and the edge of the background lawn surrounding one of the pocks illustrated in Fig. 1, were isolated using a fine wire and a low-power microscope. The samples were suspended in water and plated on CM. Samples of the resulting colonies were characterized both for the presence of SCP2* (by the Ltz reaction when replicated to lawns of strains M138 and M146) and for chromosomal genotype. The results (Table 2) indicate the occurrence of $\mathrm{SCP} 2^{*}$ a considerable distance away from growth with a chromosomal genotype corresponding to the plasmid's original host; the plasmid, but not the chromosome of the SCP2* parent, had colonized the recipient background lawn even beyond the outermost zone of inhibition. A correlation therefore exists between the 


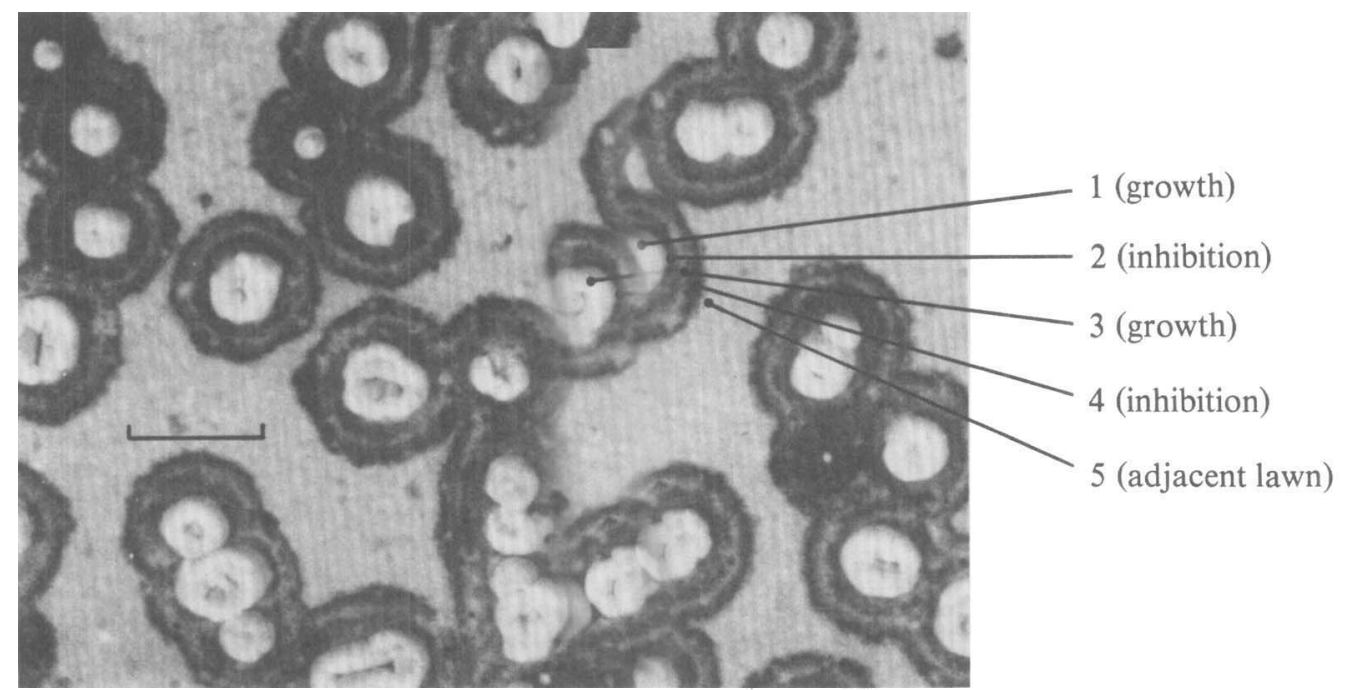

Fig. 1. Pocks produced by the growth from isolated spores of strain M111 (SCP1+SCP2*) in a lawn of strain $\mathrm{M} 138\left(\mathrm{SCP}^{+}{ }^{+} \mathrm{SCP}_{2}-\right)$. The concentric zones of one of the pocks indicated are referred to in Table 2. The bar marker represents $2 \mathrm{~mm}$.

Table 2. Analysis of genotype and plasmid status of zones within a pock

The pock analysed was one produced by growth from isolated spores of strain M111 (SCP1+SCP2*) in a lawn of strain M138 (SCP1 $\left.{ }^{+} \mathrm{SCP}^{-}\right)$. The various zones are defined in Fig. 1.

\begin{tabular}{|c|c|c|c|c|c|c|}
\hline & $\begin{array}{r}\text { SCP2 } \\
\text { colo }\end{array}$ & $\begin{array}{l}\text { ontaining } \\
\text { onies }\end{array}$ & & Genotyp & & \\
\hline Zone & Frequency & Percentage & proAl $\operatorname{argA} 1 \mathrm{cys} D 18$ & hisA uraAl strAl & Recombinants & \% Recombinants \\
\hline 1 & $300 / 300$ & 100 & 98 & 3 & 199 & 66 \\
\hline 2 & $197 / 197$ & 100 & 197 & 0 & 0 & $<0.5$ \\
\hline 3 & $193 / 200$ & 97 & 200 & 0 & 0 & $<0.5$ \\
\hline 4 & $150 / 199$ & 75 & 199 & 0 & 0 & $<0.5$ \\
\hline 5 & $38 / 200$ & 19 & 200 & 0 & 0 & $<0.5$ \\
\hline
\end{tabular}

occurrence of lethal zygosis and transfer of SCP2*. The chromosomal recombination frequency at the centre of the pock was remarkably high (at least $66 \%$ ) in comparison to a selected recombinant frequency for approximately balanced crosses between M111 and M138 (see later) of $10^{-2}-10^{-3}$ (non-selective analysis of such a cross would be expected to yield an estimate of fertility only slightly higher than that given by selective analysis).

Originally, lethal zygosis could be detected only upon transfer of the SCP2* variant to an SCP2- culture (Bibb et al., 1977). It was later found that, when R2 medium supplemented with required growth factors was used for the assay, SCP2 also exhibited lethal zygosis, but the reaction was much less intense. The difference in expression of lethal zygosis by the two plasmids may result from differences in their transfer properties (see later).

\section{Isolation of $S C P 2^{-}$derivatives}

Previously described SCP2- derivatives of $S$. coelicolor A3(2) were isolated by screening colonies for the loss of the higher fertility level of SCP2* when mated on plates with an $\mathrm{SCP}_{2}{ }^{+}$strain (Bibb et al., 1977). Attempts were later made to isolate SCP2- derivatives by screening colonies of SCP2* cultures for the loss of the Ltz reaction. This method proved to be very efficient for the isolation of $\mathrm{SCP} 2^{-}$derivatives, particularly from $\mathrm{SCP} 1^{+} \mathrm{SCP} 2^{*}$ 


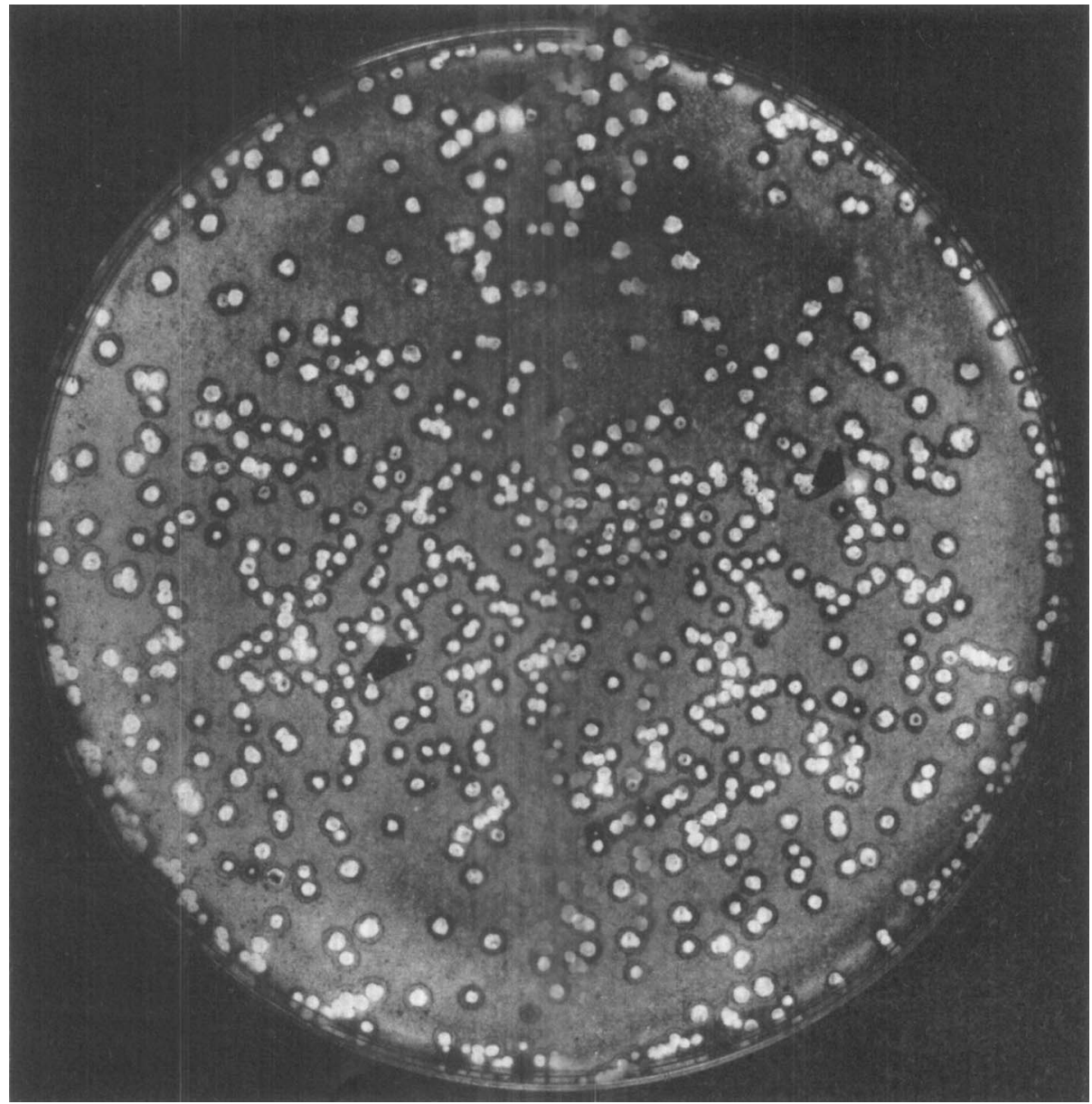

Fig. 2. Isolation of $\mathrm{SCP}^{-}$strains from among pocks produced by the growth of spores of strain M111 (SCP1 ${ }^{+}$SCP2 ${ }^{*}$ ) in a lawn of strain M138 (SCP1 ${ }^{+}$SCP2 ${ }^{-}$). Note the absence of zones of lethal zygosis around spontaneous SCP2 ${ }^{-}$variants of strain M111 (arrows).

strains which produced very distinct pocks on an SCP1+SCP2- indicator. Spores of $\mathrm{SCP} 2 *$-containing cultures were serially diluted and plated on $\mathrm{CM}$ with an excess of spores of an $\mathrm{SCP}^{-}$isolate and incubated until sporulation occurred (Fig. 2). Presumptive $\mathrm{Ltz}^{-}$ colonies on such plates were purified and all were shown to be $\mathrm{Ltz}^{\mathrm{s}}$; the failure to isolate CCC DNA from any such isolate by techniques normally yielding SCP2* further indicated their origin by plasmid loss.

The frequency of spontaneous loss of SCP2* from strains M107 and M110 had previously been estimated at $1.5 \%(13 / 857)$ and $0.5 \%(2 / 420)$, respectively (Bibb et al., 1977). The spontaneous loss of SCP2* from SCP1-containing derivatives of these two strains, screening for loss either of fertility or of lethal zygosis, occurred at the lower frequencies of $0.6 \%$ $(4 / 651)$ and $0.03 \%(1 / 3192)$, respectively.

That the strains characterized as SCP2- by the phenotypic criteria described above did indeed arise by plasmid loss and not by mutation, DNA rearrangement or integration into the chromosome has recently been shown by the failure to detect any DNA sequences homologous to radioactively labelled SCP2* DNA in several independently derived SCP1- $1^{-}{ }^{-} 2^{-}$strains by a modification of the Southern (1975) transfer technique (M. J. Bibb, unpublished results). 
Table 3. Transfer frequencies of $S C P 1, S C P 2$ and $S C P 2^{*}$

\begin{tabular}{|c|c|c|c|}
\hline \multirow[b]{2}{*}{ Cross } & \multicolumn{3}{|c|}{ Percentage transfer of each plasmid $\dagger$} \\
\hline & SCP 1 & SCP2 & SCP2* \\
\hline $\begin{array}{l}\mathrm{SCP} 1^{+} \mathrm{SCP} 2^{-} \times \mathrm{SCP} 1^{-} \mathrm{SCP} 2^{-} \\
\mathrm{SCP} 1^{+} \mathrm{SCP} 2^{+} \times \mathrm{SCP} 1^{-} \mathrm{SCP} 2^{+} \\
\mathrm{SCP} 1^{+} \mathrm{SCP} 2^{*} \times \mathrm{SCP} 1^{-} \mathrm{SCP} 2^{*}\end{array}$ & $\begin{array}{l}100 \\
100 \\
100\end{array}$ & $\begin{array}{l}\text { NA } \\
\text { ND } \\
\text { NA }\end{array}$ & $\begin{array}{l}\text { NA } \\
\text { NA } \\
\text { ND }\end{array}$ \\
\hline $\begin{array}{l}\mathrm{SCP} 1^{-} \mathrm{SCP}_{2}^{+} \times \mathrm{SCP}^{-} \mathrm{SCP}^{-} \\
\mathrm{SCP} 1^{+} \mathrm{SCP}^{+} \times \mathrm{SCP}^{-} \mathrm{SCP}^{-} \\
\mathrm{SCP} 1^{-} \mathrm{SCP} 2^{+} \times \mathrm{SCP} 1^{+} \mathrm{SCP} 2^{-} \\
\mathrm{SCP}^{+} 1^{+} \mathrm{SCP} 2^{+} \times \mathrm{SCP} 1^{+} \mathrm{SCP} 2^{-}\end{array}$ & $\begin{array}{l}\text { NA } \\
100 \\
100 \\
\text { ND }\end{array}$ & $\begin{array}{r}98 \\
98 \\
95 \\
100\end{array}$ & $\begin{array}{l}\text { NA } \\
\text { NA } \\
\text { NA } \\
\text { NA }\end{array}$ \\
\hline $\begin{array}{l}\mathrm{SCP} 1^{-} \mathrm{SCP} 2^{*} \times \mathrm{SCP} 1^{-} \mathrm{SCP} 2^{-} \\
\mathrm{SCP} 1^{+} \mathrm{SCP} 2^{*} \times \mathrm{SCP} 1^{-} \mathrm{SCP} 2^{-} \\
\mathrm{SCP} 1^{-} \mathrm{SCP} 2^{*} \times \mathrm{SCP} 1^{+} \mathrm{SCP} 2^{-} \\
\mathrm{SCP} 1^{+} \mathrm{SCP} 2^{*} \times \mathrm{SCP} 1^{+} \mathrm{SCP} 2^{-}\end{array}$ & $\begin{array}{l}\text { NA } \\
100 \\
100 \\
\text { ND }\end{array}$ & $\begin{array}{l}\text { NA } \\
\text { NA } \\
\text { NA } \\
\text { NA }\end{array}$ & $\begin{array}{r}98 \\
100 \\
98 \\
100\end{array}$ \\
\hline $\begin{array}{l}\mathrm{SCP} 1^{-} \mathrm{SCP} 2^{*} \times \mathrm{SCP}^{-}{ }^{-} \mathrm{SCP} 2^{+} \\
\mathrm{SCP} 1^{+} \mathrm{SCP} 2^{*} \times \mathrm{SCP} 1^{-} \mathrm{SCP} 2^{+} \\
\mathrm{SCP} 1^{-} \mathrm{SCP} 2^{*} \times \mathrm{SCP} 1^{+} \mathrm{SCP} 2^{+} \\
\mathrm{SCP} 1^{+} \mathrm{SCP} 2^{*} \times \mathrm{SCP} 1^{+} \mathrm{SCP} 2^{+}\end{array}$ & $\begin{array}{r}\text { NA } \\
99 \\
100 \\
\text { ND }\end{array}$ & $\begin{array}{l}<0.7 \\
<0.6 \\
<0.6 \\
<0.7\end{array}$ & $\begin{array}{r}11 \\
6 \\
98 \\
94\end{array}$ \\
\hline
\end{tabular}

$\dagger$ NA, Not applicable; ND, not detectable. Transfer frequencies are expressed per recipient genotype and are average values from three or four crosses, including crosses of genotypes proAlargAl cysDI8 $\times$ hisAl uraAl strAl and pheAl $\times$ hisAl uraAl strAl; at least 100 colonies of each genotype were characterized for plasmid status in each cross.

\section{Transfer and fertility properties of SCP2 and SCP2*}

To determine the roles of SCP2* and SCP2 as fertility plasmids, a series of crosses between $S$. coelicolor A3(2) derivatives differing in a set of chromosomal markers and including all possible combinations of status in respect of SCP1, SCP2 and SCP2* was analysed by counting the colonies recovered on media selective for each parental genotype and on two media selecting recombinants. In addition, the plasmid status of samples of parental genotypes from the crosses were characterized by the plate-crossing technique.

Transfer properties of SCP2 and SCP2*. Data on the transfer frequencies of SCP1, SCP2 and SCP2* are summarized in Table 3. Appropriate plasmid-minus recipient strains received each plasmid at a frequency of $95-100 \%$; SCP 1 was not needed for efficient transfer, nor did it interfere with transfer of SCP2 or SCP2*, and vice versa. In crosses between SCP2* and $\mathrm{SCP} 2^{+}$strains there was never any detectable transfer of SCP2 into the SCP2*-containing strain, irrespective of the presence or absence of SCP1 in either parent, but some transfer of SCP2* into the SCP2+ strain was invariably observed; thus SCP2* differs from SCP2 in some character related to transfer or establishment after transfer. The most surprising result was the effect of SCP1, in the recipient, on the frequency of transfer of SCP2* to an SCP2+ strain. In the absence of SCP1 in either strain, this frequency was $11 \%$ and was not significantly different $(6 \%)$ if SCP 1 was present in the SCP2* partner. However, when SCP 1 was present in the SCP $2^{+}$strain (or in both strains), the transfer frequency of SCP $2^{*}$ into the $\mathrm{SCP} 2{ }^{+}$recipient was $94-98 \%$.

Effect of SCP1, SCP2 and SCP2* on the frequency of chromosomal recombination. Approximate chromosomal recombination frequencies in crosses involving SCP1, SCP2 and SCP2* in all combinations are summarized in Table 4 . In the absence of SCP1, matings between two SCP2- isolates produced few $\left(10^{-8}\right)$ recombinants (they were confirmed as recombinants, rather than spontaneous revertants by their possession of auxotrophic markers of each parent), suggesting that the two plasmids are responsible for most, but not all, of the fertility normally observed amongst marked derivatives of $S$. coelicolor A3(2). There was 
Table 4. Approximate recombination frequencies in crosses involving $S C P 1, S C P 2$ and $S C P 2^{*}$

\begin{abstract}
The parental genotypes were proAl $\arg A 1 \mathrm{c}$ sD 18 and hisAl uraAl strAl. Recombination frequencies are the average numbers of recombinants on media selecting his $A^{+}$and $\operatorname{strAl}$ or $\arg A^{+}$and $u r a A^{+}$as a fraction of the numbers of colonies on media selecting the parental genotypes. Reversing the plasmid status of the parental strains had little effect on the fertility of the mating; the results represent the recombination frequencies of crosses with either polarity.
\end{abstract}

SCP1 ${ }^{-} \mathrm{SCP}_{2}-\mathrm{SCP}^{-}{ }^{-} \mathrm{SCP} 2^{+} \mathrm{SCP}^{-} \mathrm{SCP}^{*} \mathrm{SCP}^{+} \mathrm{SCP} 2^{-} \mathrm{SCP} 1^{+} \mathrm{SCP} 2^{+} \mathrm{SCP} 1^{+} \mathrm{SCP} 2^{*}$

\begin{tabular}{|c|c|c|c|c|c|c|}
\hline $\mathrm{SCP}^{-}{ }^{-} \mathrm{SCP} 2^{-}$ & $10^{-8}$ & - & - & - & - & - \\
\hline $\mathrm{SCP}_{1}{ }^{-} \mathrm{SCP}_{2}+$ & $10^{-6}$ & $10^{-7}$ & - & - & - & - \\
\hline $\mathrm{SCP} 1^{-} \mathrm{SCP} 2^{*}$ & $10^{-3}$ & $10^{-5}$ & $10^{-3}$ & - & - & - \\
\hline $\mathrm{SCP}_{1}{ }^{+} \mathrm{SCP} 2^{-}$ & $10^{-6}$ & $10^{-5}$ & $10^{-2}-10^{-3}$ & $10^{-5}$ & - & - \\
\hline $\mathrm{SCP}_{1}{ }^{+} \mathrm{SCP} 2^{+}$ & $10^{-5}$ & $10^{-6}$ & $10^{-3}$ & $10^{-5}$ & - & - \\
\hline $\mathrm{SCP} 1^{+} \mathrm{SCP} 2^{*}$ & $10^{-2}-10^{-3}$ & $10^{-4}$ & $10^{-2}-10^{-3}$ & $10^{-2}-10^{-3}$ & $10^{-3}$ & $10^{-3}$ \\
\hline
\end{tabular}

some evidence that the pattern of marker inheritance in $\mathrm{SCP} 1^{-} \mathrm{SCP} 2^{-} \times \mathrm{SCP}^{-} \mathrm{SCP} 2^{-}$ crosses might be different from that seen when one of the known plasmids was present, but a deeper study would be needed to characterize any such difference.

When SCP2 was present in both parents, the level of fertility $\left(10^{-7}\right)$ was about ten times that of the 'background' level found in its absence; it was a further ten times higher when SCP2 was present in only one parent. SCP2* in one or both parents increased the frequency of recombination by a factor of $10^{5}$ compared with the 'background' level, to the high value of $10^{-3}$; however, when SCP2* was present in one parent and SCP2 in the other, the fertility was only about $10^{-5}$.

SCP1 was first recognized because of its role in the fertility of $S$. coelicolor A3(2) (Hopwood et al., 1969; Vivian \& Hopwood, 1970), but SCP2 (and perhaps SCP2* in some cases) was present, undetected, at the time. We therefore re-examined the effects of SCP1, using SCP2 ${ }^{-}$strains. Crosses between $\mathrm{SCP} 1^{+} \mathrm{SCP}^{-}$and SCP1- $1^{-} \mathrm{SC} 2^{-}$strains (Table 4) exhibited 10-100-fold more chromosomal recombination than the corresponding SCP1-SCP2- matings. However, in contrast to the situation with SCP2, crosses between two $\mathrm{SCP} 1^{+}$derivatives were at least as fertile as the corresponding $\mathrm{SCP} 1^{+} \times \mathrm{SCP}^{-}$matings. In this way SCP1 resembles SCP2*, which may indicate some functional similarity between the two plasmids; perhaps SCP1 is a naturally occurring SCP2*-like variant of a pre-existing plasmid.

No significant interaction was observed between SCP2 and SCP1 as fertility determinants; the abilities of the two plasmids to promote chromosomal recombination appeared to be additive when both were present. All of the crosses involving SCP1 and SCP2* produced chromosomal recombinants at a frequency consistent with the properties of SCP2* and the effect of SCP1 on SCP2* transfer. The latter effect is shown by the enhanced fertility of $\mathrm{SCP} 1^{+} \mathrm{SCP} 2^{+} \times \mathrm{SCP} 1^{-} \mathrm{SCP} 2^{*}$ matings $\left(10^{-3}\right)$ and SCP $1^{+} \mathrm{SCP} 2^{*} \times \mathrm{SCP} 1^{-} \mathrm{SCP} 2^{+}$matings $\left(10^{-4}\right)$ compared with the corresponding SCP1- $1^{-} \mathrm{SCP} 2^{*} \times \mathrm{SCP} 1^{-} \mathrm{SCP} 2^{+}$matings $\left(10^{-5}\right)$ even when allowing for SCP1-mediated chromosomal recombination; presumably, in the $\mathrm{SCP} 1^{+} \mathrm{SCP} 2^{*} \times \mathrm{SCP} 1^{-} \mathrm{SCP} 2^{+}$cross, early transfer of $\mathrm{SCP} 1$, converting the $\mathrm{SCP} 1^{-}$strain to $\mathrm{SCP} 1^{+}$, is responsible for this effect.

High frequency transfer. A simple hypothesis for the nature of SCP2* is that it is a partially derepressed variant of SCP2 with enhanced transfer properties; the unequal transfer frequencies of SCP2 and SCP2* in matings involving the two plasmids supports this suggestion. On this hypothesis, the majority of an originally $\mathrm{SCP} 2^{-}$genotype obtained from a triparental cross involving a strain of each type, SCP2*, SCP2 ${ }^{+}$and $\mathrm{SCP} 2^{-}$, should possess SCP2* rather than SCP2. Several triparental crosses and biparental control matings were made and the parental genotypes which emerged were characterized for plasmid status using both the fertility and Ltz phenotypes (Table 5). As predicted by the hypothesis, the majority 
Table 5. Transfer frequencies of $S C P 2$ and $S C P 2 *$ in triparental compared with biparental matings (in the absence of SCP1)

\begin{tabular}{|c|c|c|c|}
\hline \multirow[b]{2}{*}{ Cross } & \multirow{2}{*}{$\begin{array}{l}\text { Ratio of colony counts } \\
\text { on media recovering } \\
\text { parental genotypes }\end{array}$} & \multicolumn{2}{|c|}{ Plasmid status after mating $(\%)$} \\
\hline & & $\mathrm{SCP} 2^{*}$ & $\mathrm{SCP}^{+}$ \\
\hline $\begin{array}{r}\text { M133 }\left(\text { SCP2 }^{*}\right) \times \\
1098\left(\mathrm{SCP}^{+}\right) \times \\
\left.\text {M130(SCP2 }{ }^{-}\right)\end{array}$ & $\begin{array}{r}42 \\
3 \\
1\end{array}$ & $\begin{array}{l}91 \\
57 \\
88\end{array}$ & $\begin{array}{r}9 \\
43 \\
12\end{array}$ \\
\hline $\begin{array}{r}\text { M133 }\left(\mathrm{SCP}^{*}\right) \times \\
1098\left(\mathrm{SCP}^{+}\right) \times \\
\left.\text {M130(SCP2 }{ }^{-}\right)\end{array}$ & $\begin{array}{r}145 \\
1 \\
8\end{array}$ & $\begin{array}{l}96 \\
57 \\
90\end{array}$ & $\begin{array}{r}4 \\
43 \\
10\end{array}$ \\
\hline $\begin{array}{r}\left.\text { M107(SCP2 } 2^{*}\right) \times \\
1190\left(\mathrm{SCP}^{+}\right) \times \\
\left.\text {M132(SCP2 }{ }^{-}\right)\end{array}$ & $\begin{array}{r}34 \\
12 \\
1\end{array}$ & $\begin{array}{r}92 \\
8 \\
51\end{array}$ & $\begin{array}{r}8 \\
92 \\
49\end{array}$ \\
\hline $\begin{array}{l}\left.\text { M109(SCP2 } 2^{*}\right) \times \\
\text { A700 }\left(\mathrm{SCP}^{+}\right) \times \\
\left.\text {M130 (SCP2 }{ }^{-}\right)\end{array}$ & $\begin{array}{c}1 \cdot 3 \\
24 \\
1\end{array}$ & $\begin{array}{r}100 \\
100 \\
96\end{array}$ & $\begin{array}{l}<0.6 \\
<0.5 \\
4\end{array}$ \\
\hline $\begin{array}{l}\text { M109 }\left(\text { SCP2 }^{*}\right) \times \\
\left.\text { A700 (SCP2 } 2^{+}\right) \times \\
\left.\text {M130 (SCP2 }{ }^{-}\right)\end{array}$ & $\begin{array}{l}1 \\
63 \\
6 \cdot 7\end{array}$ & $\begin{array}{r}100 \\
99 \\
99\end{array}$ & $\begin{array}{r}<1 \\
1 \\
1\end{array}$ \\
\hline $\begin{array}{l}\left.\text { M110 (SCP2 } 2^{*}\right) \times \\
\left.\text { A700 (SCP2 } 2^{+}\right) \times \\
\left.\text {M132(SCP2 } 2^{-}\right)\end{array}$ & $\begin{array}{r}1 \\
1520 \\
15\end{array}$ & $\begin{array}{l}96 \\
95 \\
91\end{array}$ & $\begin{array}{l}3 \\
5 \\
9\end{array}$ \\
\hline $\begin{array}{c}\text { M133 (SCP2*)X } \\
1098\left(\text { SCP2 }^{+}\right)\end{array}$ & $\begin{array}{l}1 \\
3 \cdot 4\end{array}$ & $\begin{array}{r}100 \\
5\end{array}$ & $\begin{array}{l}<1 \\
95\end{array}$ \\
\hline $\begin{array}{c}\text { M107 }\left(\mathrm{SCP}^{*}\right) \times \\
1190\left(\mathrm{SCP}^{+}\right)\end{array}$ & $\begin{array}{l}1 \\
1\end{array}$ & $\begin{array}{r}99 \\
4\end{array}$ & $\begin{array}{r}1 \\
96\end{array}$ \\
\hline $\begin{array}{l}\left.\text { M109(SCP2 }{ }^{*}\right) \times \\
\text { A700 }\left(\text { SCP2 }^{+}\right)\end{array}$ & $\begin{array}{r}1 \\
115\end{array}$ & $\begin{array}{r}100 \\
8\end{array}$ & $\begin{array}{l}<1 \\
92\end{array}$ \\
\hline
\end{tabular}

of the original SCP2- genotype received SCP2*, not SCP2, even when the parental SCP2+ donor genotype was much more abundant than the SCP2* type. Moreover, the frequency of transfer of SCP2* into the SCP2+ parental genotype (50-100\% except in one cross) was much greater than that observed in the corresponding bi-parental crosses $(4-8 \%)$. This probably represents a phenomenon analogous to the high frequency transfer (HFT) state of other sex factors, such as Coll (Stocker et al., 1963). On entering an SCP2- host, genes involved in the transfer of SCP2* would become derepressed, making the original plasmid recipient an enhanced plasmid donor, and resulting in a higher frequency of transfer of SCP2* into SCP2 ${ }^{+}$strains. The fact that four out of six of the triparental crosses showed significant frequencies (3-9\%) of conversion of the SCP2* parental genotype to SCP2 ${ }^{+}$, which was never seen in biparental crosses, suggests a temporary derepression also of SCP2 when transferred to SCP2- mycelium. The ratio of the apparent 'back transfer' frequencies of SCP2* and SCP2 agreed very well with the ratio of SCP2* and SCP2 ${ }^{+}$amongst the progeny originally having the SCP2- parental genotype.

$S C P 2, S C P 2^{*}$ and chromosome mobilization. SCP2 and SCP2* might promote chromosomal recombination by interacting physically with the chromosome, resulting in the transfer of short chromosomal fragments from the donor to the recipient, as reported for $\mathrm{F}$ in Escherichia coli; there is evidence for such an effect for SCP1 in S. coelicolor (Hopwood et al., 1973). Several duplicate crosses with alternative plasmid couplings were therefore carried out between various $\mathrm{SCP} 2^{*}$ or $\mathrm{SCP}_{2}{ }^{+}$strains and SCP2- isolates of complementary chromosomal genotypes, and samples of the resulting recombinants were analysed to produce 

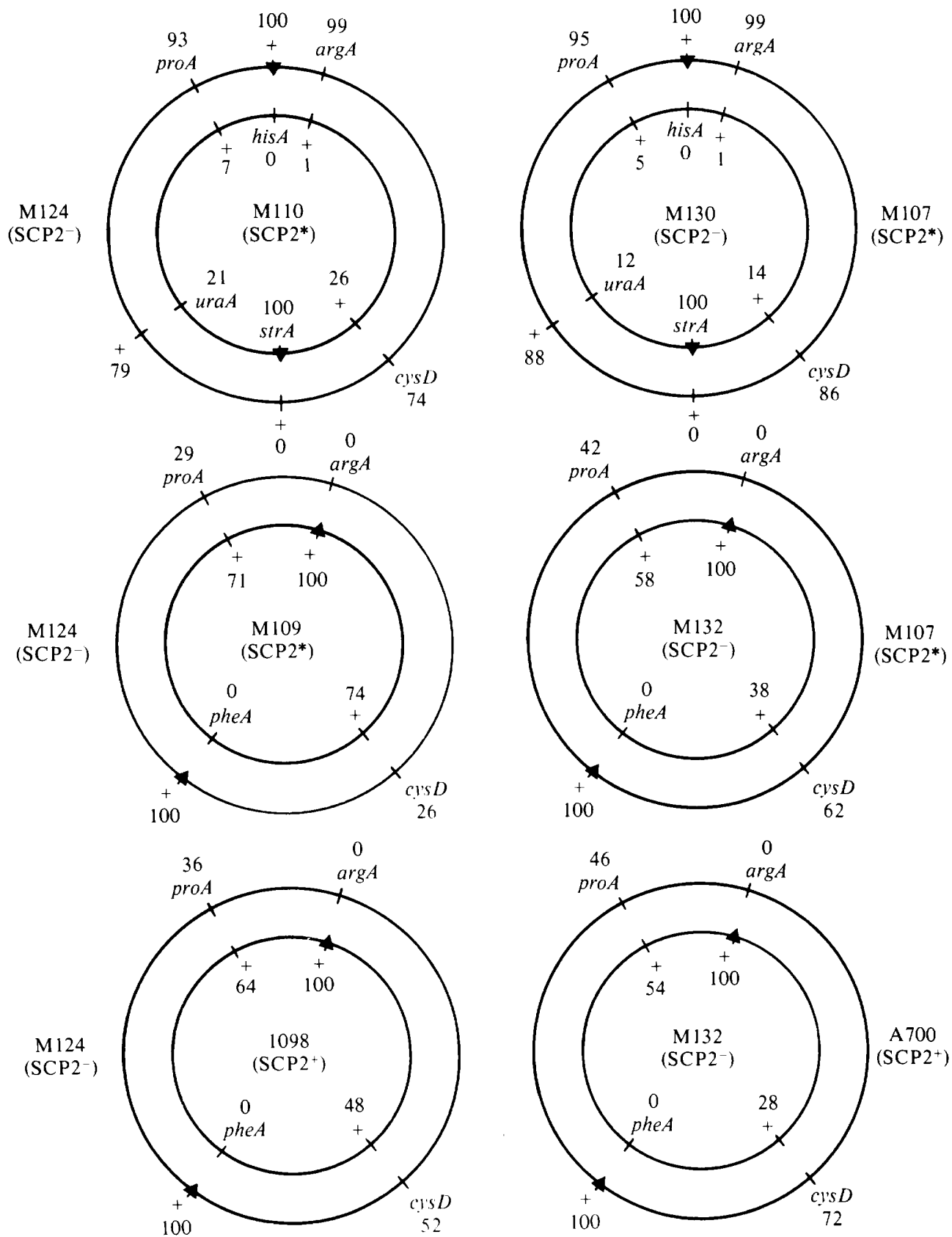

Fig. 3. Allele gradients (\%) amongst recombinants selected from $\mathrm{SCP}_{2}^{*} \times \mathrm{SCP}^{-}$and $\mathrm{SCP}_{2}^{+} \times$ $\mathrm{SCP} 2^{-}$crosses. Triangles indicate selected alleles. Note that in each pair of figures the coupling of plasmid status with chromosomal genotype is reversed.

allele gradients for each mating (Fig. 3). No evidence was obtained to suggest that strains containing either SCP2* or SCP2 consistently served as donors of short chromosomal fragments to the SCP2- parent; this would have been revealed by a steep gradient in the allele frequencies on either side of each selected allele from the SCP2* parent. Moreover, reversal of the plasmid coupling of the matings did not always result in a change in allele ratios which 
Table 6. Frequency of new SCP2*-like variants amongst selected recombinants from $S C P 2^{+} \times S C P 2^{+}$crosses

\begin{tabular}{|c|c|c|c|}
\hline \multirow[b]{2}{*}{ Cross } & \multirow[b]{2}{*}{ Selected alleles } & \multicolumn{2}{|c|}{ High fertility variants } \\
\hline & & Frequency & Percentage \\
\hline $\mathrm{A} 700\left(\mathrm{SCP}^{-}\right) \times 1190\left(\mathrm{SCP}^{-}\right)$ & his $A^{+} \sin A 1$ & $30 / 465$ & 6 \\
\hline $1098\left(\mathrm{SCP}^{-}\right) \times 1190\left(\mathrm{SCP}_{1-}^{-}\right)$ & hisA $A^{+}$strAl & $14 / 197$ & 7 \\
\hline $1516\left(\mathrm{SCP1}^{-}\right) \times 1705\left(\mathrm{SCP}^{-}\right)$ & hisC $C^{+}$phe $A^{+}$ & $4 / 185$ & 2 \\
\hline $2278\left(\mathrm{SCP}^{+}\right) \times 1190\left(\mathrm{SCP}^{+} 1^{-}\right)$ & $\operatorname{hisA}^{+} \operatorname{strAl}$ & $2 / 100$ & 2 \\
\hline $2278\left(\mathrm{SCP}^{+}\right) \times 104\left(\mathrm{SCP}^{+} 1^{+}\right)$ & his $A^{+} \operatorname{sir} A l$ & $3 / 187$ & $1 \cdot 6$ \\
\hline $12\left(\mathrm{SCP} 1^{+}\right) \times 104\left(\mathrm{SCP} 1^{+}\right)$ & his $A^{+} \operatorname{str} A 1$ & $24 / 108$ & 22 \\
\hline
\end{tabular}

would have indicated that SCP2 and SCP2* did play an important role in determining the nature of the gene transfer which occurred during conjugation; such changes as did occur (Fig. 3) were not large. Moreover, no evidence was obtained to indicate the preferential inheritance of any particular region of the chromosome during matings involving either SCP2 or SCP2*.

\section{Isolation and characterization of new SCP2* variants}

As reported previously (Bibb et al., 1977), new SCP2* variants could be found amongst recombinants produced in matings between $\mathrm{SCP} 2^{+}$strains. These studies were extended as described below.

Samples of recombinants from a series of matings between $\mathrm{SCP}^{+}{ }^{+}$strains were characterized for their fertility properties by the plate-crossing technique. An average of $6 \%$ of the recombinants $(48 / 847)$ obtained in the absence of SCP1 possessed fertility characteristics resembling those of SCP2* (Table 6). A similar frequency $(29 / 395=7 \%$ ) of SCP2*-like variants was obtained amongst recombinants from crosses between parents one or both of which contained SCP1. Since most of the recombinants from such matings should have resulted from the involvement of SCP1, SCP2*-like variants might have been less frequent in the presence of SCP1. Probably the effect of SCP1 on the transfer properties of SCP2*, reported earlier, explains the observed results. Attempts to isolate variants with enhanced fertility properties amongst recombinants obtained in matings between SCP1-SCP2 ${ }^{-}$cultures failed (0/435 recombinants).

The fertility properties of 11 of the new variants were analysed quantitatively. Each new variant transferred its enhanced fertility infectiously to SCP1-SCP2 ${ }^{+}$(strain 1190) and $\mathrm{SCP}_{1}{ }^{+} \mathrm{SCP}_{2}{ }^{+}$(strain 104) derivatives. Transfer into the $\mathrm{SCP} 1^{+}$strain was invariably $94-100 \%$, as in the case of the original SCP2* variant, but transfer into the SCP $1^{-} \mathrm{SCP} 2^{+}$ strain was sometimes more efficient (up to $74 \%$ compared with $5-11 \%$ for the original $\mathrm{SCP} 2 *$ isolate). The new variants also exhibited higher levels of recombination, particularly in matings with strain 1190 , than the original SCP2* isolate. These observations may indicate a difference between the new isolates and the original SCP2*, although effects of background genotypes cannot be discounted.

All of the new isolates expressed lethal zygosis characteristic of SCP2* when replicated to a lawn of an appropriate SCP2 $2^{-}$culture (and none on an $\mathrm{SCP}_{2}{ }^{+}$lawn), suggesting that enhancement of lethal zygosis was a general phenomenon accompanying the increase in fertility of SCP2 to the level exhibited by SCP2*.

\section{Isolation of SCP2* fertility-defective mutants}

The fertility exhibited by SCP2* strains presumably depends on several factors, including both plasmid-determined functions (e.g. plasmid transfer and possibly specific chromosomal mobilization) and chromosomally located functions (e.g. recombination). During the procedure initially adopted for the recognition of spontaneously occurring SCP2- derivatives 


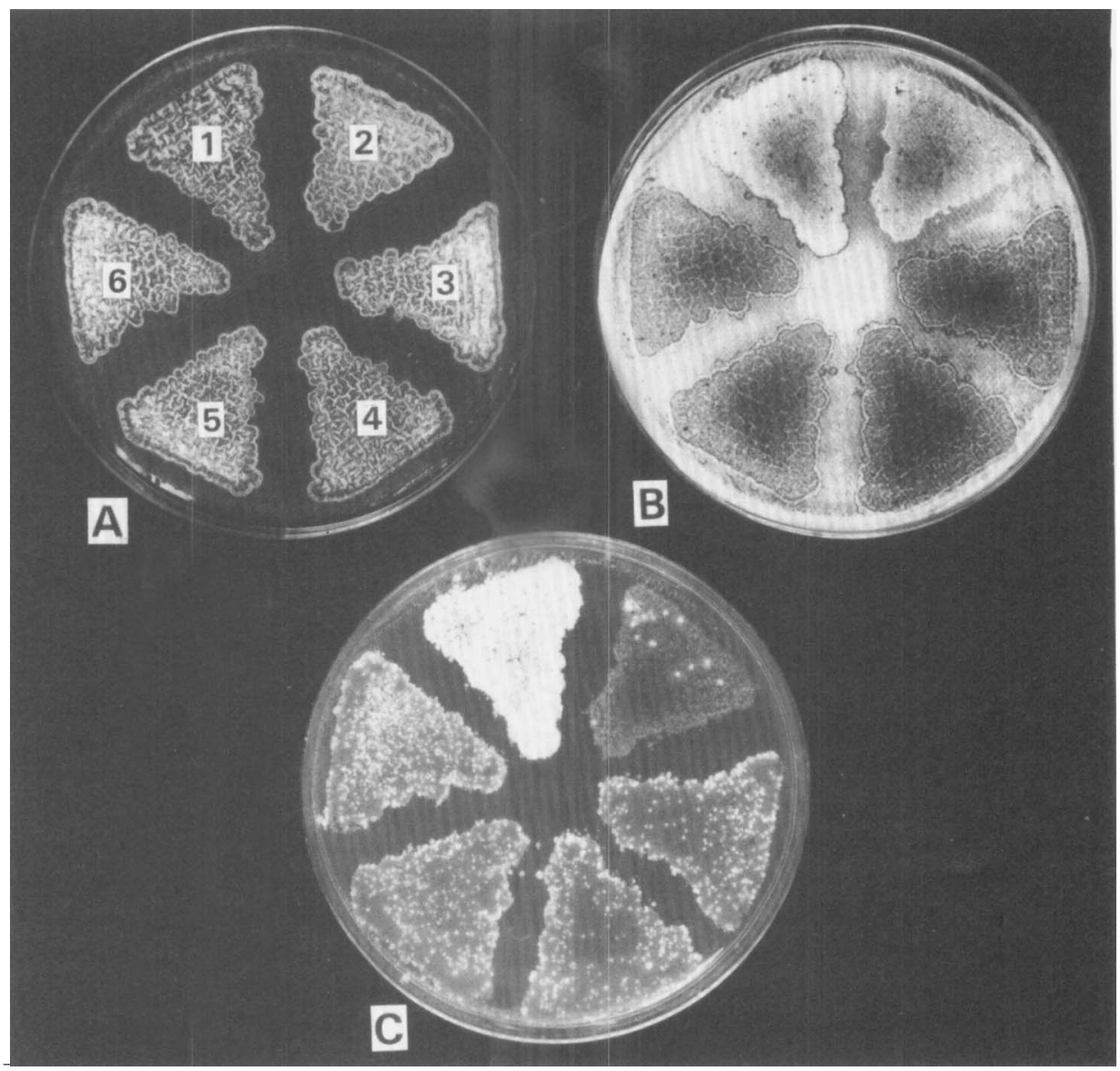

Fig. 4. Lethal zygosis with reduced chromosomal fertility in fertility-defective SCP2*d derivatives (see footnote to Table 1) of SCP2* strains. The master plate (A) was replicated to a lawn of strain $\mathrm{M} 138$ (SCP $1^{+} \mathrm{SCP}^{-}$) and the resulting plate cross (B) was replicated to a medium (C) selective for recombinants inheriting $\arg A^{+}$and $\mathrm{uraA}^{+}$. Strains: $1, \mathrm{M} 111$ (SCP1+SCP2*); 2, $104\left(\mathrm{SCP} 1^{+} \mathrm{SCP} 2^{+}\right) ; 3$ and 4, M148 (SCP1 ${ }^{+}$SCP2 $\left.{ }^{* d}\right) ; 5$ and 6, M $147\left(\mathrm{SCP}^{+}{ }^{+} \mathrm{SCP} 2^{* d}\right)$. Note that strains M 147 and M 148 are capable, like the parental M111 strain, of eliciting lethal zygosis on strain M138, but show a much reduced level of chromosomal fertility (though still slightly higher than that of SCP2 in strain 104).

Table 7. Properties of SCP2* fertility-defective mutants $M 147$ and M148 compared with $S C P 2^{*}$ strain $M 111$

\begin{tabular}{|c|c|}
\hline \multicolumn{2}{|c|}{ Parent strains } \\
\hline $\begin{array}{l}\text { Plasmid } \\
\text { donor }\end{array}$ & $\begin{array}{l}\text { Plasm } \\
\text { recipie }\end{array}$ \\
\hline M 147 & \\
\hline M 148 & MI \\
\hline M111 & M 13 \\
\hline
\end{tabular}

\begin{tabular}{|c|c|}
\hline $\begin{array}{l}\text { Per plasmid } \\
\text { donor }\end{array}$ & $\begin{array}{l}\text { Per plasmid } \\
\text { recipient }\end{array}$ \\
\hline $8.8 \times 10^{-4}$ & $2.3 \times 10^{-3}$ \\
\hline $1.3 \times 10^{-4}$ & $8.6 \times 10^{-4}$ \\
\hline $1.0 \times 10^{-2}$ & $6.4 \times 10^{-3}$ \\
\hline
\end{tabular}

Transfer
frequency
of SCP2* $(\%)$
97
98
100

from strain M111 (SCP1+SCP2*) by loss of the fertility properties associated with SCP2*, two possibly clonal derivatives (M147 and M148) were obtained which exhibited a marked reduction in fertility, yet retained the ability to express SCP2*-determined lethal zygosis (Fig. 4). The level of chromosomal recombination obtained in matings of M147 or M148 with M138 (Table 7) was significantly lower than that observed for their progenitor, M111, even 


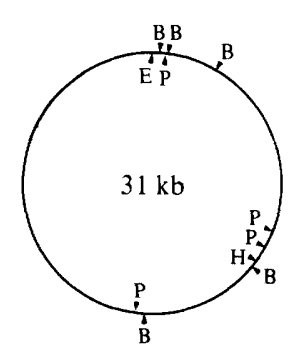

(a)

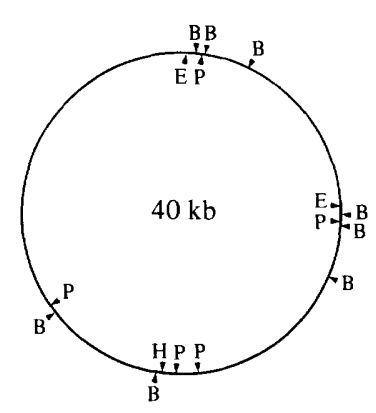

(b)

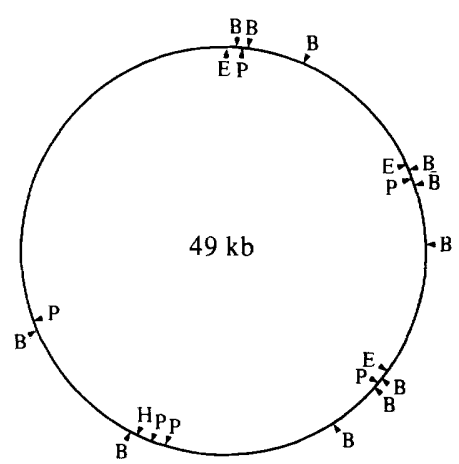

(c)

Fig. 5. Restriction endonuclease cleavage maps of SCP2* $(a)$ and of SCP2*TR derivatives (see footnote to Table 1) carrying one $(b)$ and two $(c)$ extra copies of a $9 \mathrm{~kb}$ sequence in tandem duplication. Cleavage sites: B, BamHI; E, EcoRI; H, HindIII; P, PstI (ESalPI).

though the transfer frequency of the presumptive SCP2* plasmid from M147 and M 148, as determined by the Ltz phenotype of the progeny, approached $100 \%$. The reduction in fertility was found to be SCP2* linked since $\mathrm{Ltz}^{+}$isolates of M138 obtained from the crosses with M147 and M148 exhibited a marked reduction in fertility when compared with the chromosomally isogenic SCP1+SCP2* strain M 108.

These results, together with those in the preceding section, show the existence of a range of SCP2 variants promoting varying levels of chromosomal fertility, from that of SCP2 itself to that of the most fertile SCP2* variants.

\section{Interspecific transfer of SCP2*}

Attempts were made to transfer SCP2* interspecifically from $S$. coelicolor A3(2) to $S$. parvulus (strains 2283 and 2296) and S. lividans (strain 1326), recognizing transconjugants by their ability to elicit lethal zygosis (i.e. to produce pocks). Dilutions of spores obtained from the interspecific matings were plated on selective media preventing growth of the original plasmid donor but in the presence of an added excess of the potential recipient sufficient to produce a confluent lawn of growth. Putative SCP2*-containing strains of both $S$. lividans and $S$. parvulus were obtained and the presence of SCP2* was confirmed by the isolation and restriction endonuclease analysis of CCC DNA from $\mathrm{Ltz}^{+}$derivatives of both species (cultures of the $S$. parvulus and $S$. lividans parental strains used in the interspecific matings failed to yield any CCC DNA).

As in the case of intraspecific transfer in S. coelicolor, the presence of SCP 1 in the recipient strain significantly increased the frequency of transfer of SCP2* into it: in $S$. parvulus the frequency of transfer of SCP2* was about $2 \times 10^{-4}$ in the absence of SCP 1 and $40-50 \%$ in its presence; in $S$. lividans the frequencies were $8 \times 10^{-3}$ and $11 \%$, respectively.

\section{Isolation and characterization of SCP2* carrying a tandemly repeated sequence}

Although three of the $S$. parvulus SCP1+ $1^{+} \mathrm{SCP} 2^{*}$ isolates tested contained CCC DNA which appeared to be identical to $\mathrm{SCP} 2^{*}$ by restriction endonuclease analysis, one isolate (M151) yielded plasmid DNA with a different restriction pattern. Analysis of samples of this DNA undigested and cleaved with EcoRI, HindIII, BamHI, Pst I, SalGI or BglII indicated that it contained SCP2* $(31 \mathrm{~kb})$ and a series of larger plasmids $(40,49,58 \mathrm{~kb})$ apparently consisting of the whole of SCP2* with 1 to 3 additional copies of a directly repeated $9 \mathrm{~kb}$ sequence found uniquely within SCP2* (Fig. 5). 
SCP2 and unstable chloramphenicol resistance in S. coelicolor A3(2)

Freeman et al. (1977) reported unstable and reversible chloramphenicol resistance in both $S$. coelicolor $\mathrm{A} 3(2)$ and $S$. lividans 66 and proposed the involvement of some kind of transposable genetic element that might be capable of extrachromosomal existence. A role for SCP1 in determining chloramphenicol resistance was easily eliminated but an effect of SCP2 or SCP2* had not been ruled out despite the fact that no physical differences could be seen in SCP2 CCC DNA isolated from chloramphenicol resistant and sensitive isolates.

Evidence for the lack of any obligate involvement of SCP2 or SCP2* in chloramphenicol resistance was provided by the availability of $\mathrm{SCP} 2^{-}$strains, which exhibited the same level of chloramphenicol resistance as $\mathrm{SCP} 2 *$ and $\mathrm{SCP} 2{ }^{+}$strains and gave rise to sensitive variants $\left(\mathrm{Cml}^{\mathrm{S}}\right)$ at similar (high) frequencies. The $\mathrm{SCP} 2^{-} \mathrm{Cml}^{\mathrm{s}}$ strains in turn gave rise to chloramphenicol resistant 'revertants' $\left(\mathrm{Cml}^{\mathrm{R}}\right)$ at a characteristic (low) frequency, just as in the presence of SCP2. Hence, in the absence of SCP2 or SCP2*, the characteristics of unstable chloramphenicol resistance appeared to be identical to those observed in plasmid-containing strains.

In an attempt to detect any association between SCP2 or SCP2* and transfer of the $\mathrm{Cml}^{\mathrm{R}}$ determinant in matings, crosses were made between $\mathrm{Cml}^{\mathrm{S}}$ isolates of various $S$. coelicolor $\mathrm{A} 3$ (2) derivatives and $\mathrm{Cml}^{\mathrm{R}}$ strains containing either SCP2* or SCP2. Differences in the chloramphenicol status of the parental strains had no effect on the levels of chromosomal recombination observed, irrespective of the presence or absence of SCP2, SCP2* or SCP1, indicating that the $\mathrm{Cml}^{\mathrm{R}}$ determinant played no role in the fertility system of $S$. coelicolor A3(2). Furthermore, the apparent 'transfer frequency' of $\mathrm{Cml}^{\mathrm{R}}$ (that is the proportion of the sensitive parental genotype becoming resistant) was always far lower (by a factor of 40 to 4000 ) than the frequencies of detectable transfer of SCP2* into an SCP2 ${ }^{+}$strain. In fact, no evidence was obtained to suggest a specific transfer of chloramphenicol resistance from $\mathrm{Cm}^{\mathrm{R}}$ to $\mathrm{Cml}^{\mathrm{S}}$ derivatives; the occurrence of $\mathrm{Cml}^{\mathrm{R}}$ isolates amongst the originally $\mathrm{Cml}^{\mathrm{S}}$ parental genotype could have been due to a combination of chromosomal recombination and reversion of the $\mathrm{Cml}^{\mathrm{S}}$ determinant.

\section{Attempts to detect other SCP2-determined characters}

Antibiotic and metal ion resistance. Isogenic sets of strains of SCP2 ${ }^{*}, \mathrm{SCP}_{2}^{+}$and $\mathrm{SCP} 2^{-}$ status (M110, 1190, M130 and M107, A700, M124) were tested for their sensitivity to a series of metal salts: no differences in the diameter of inhibition zones were observed. The metals ions tested were: antimony, bismuth, cadmium, cobalt, copper, lead, manganese, mercury, molybdenum, nickel, silver, tin, uranium and zinc. In similar tests, no differences in sensitivity to the following antibiotics were observed: gentamicin, kanamycin, neomycin, streptomycin, erythromycin, tetracycline, bacitracin, polymyxin B and colistin.

Phage resistance. Eleven phages known to be capable of forming plaques on the wild-type $S$. coelicolor $\mathrm{A} 3(2)\left(\mathrm{SCP} 1^{+} \mathrm{SCP} 2^{+}\right)$were found to be equally effective in attacking $\mathrm{SCP} 1^{-}$ strains of SCP2*, $\mathrm{SCP} 2^{+}$or $\mathrm{SCP} 2^{-}$status.

Bacteriocin production. It was noted by J. E. Dowding (unpublished results) that $S$. coelicolor A3(2) produces at least one bacteriocin capable of inhibiting the growth of several streptomycetes unrelated to S. coelicolor A3(2). Evidence for the bacteriocin-like nature of the inhibitory material was provided by its high molecular weight (it failed to pass through dialysis membranes and it was sedimented by centrifugation at $100000 \mathrm{~g}$ for several hours: $\mathrm{I}$. G. Stevenson, unpublished results) and its inactivation by brief heating at $100^{\circ} \mathrm{C}$. Calcium ions (at about $4 \mathrm{~mm}$ or above) are required for the lethal action of the bacteriocin. Calcium ions at a similar concentration are required during the production of the bacteriocin for activity against some strains (e.g. S. coelicolor Müller), but not others (e.g. S. parvulus ATCC 12434) (D. A. Hopwood, I. G. Stevenson \& H. M. Wright, unpublished results); this may indicate the presence of more than one bacteriocin. 
In the present work it was found that bacteriocin production by strains M107 (SCP2*), M124 (SCP2-), M110 (SCP2*) and M130 (SCP2 ${ }^{-}$), grown in the presence or absence of added calcium ions, showed identical bacteriocin reactions against $S$. coelicolor Müller and $S$. parvulus ATCC 12434. Neither M107 nor M124 was inhibited by culture filtrates of any of the four strains, but strains M110 and M130 did show some inhibition by filtrates of all four strains; this inhibitory activity was abolished by boiling the filtrates for a few minutes. Thus, no effect of SCP2* on production of or sensitivity towards any inhibitory agent was detected. The inhibition of strains M110 and M130, but not M107 or M124, even by culture filtrates of the same strains, was evidently due to some uncharacterized effect of background genotype rather than status in respect of known plasmids.

Ultraviolet sensitivity. Survival curves for strains M110 (SCP2*), $1190\left(\mathrm{SCP} 2^{+}\right)$and $\mathrm{M} 130$ (SCP2 ${ }^{-}$), down to a kill of $99.9 \%$, were virtually superimposable, and had the characteristic shoulder and exponential regions previously found for other $S$. coelicolor A3(2) derivatives (Harold \& Hopwood, 1970).

\section{DISCUSSION}

SCP2 and SCP2* are transmissible plasmids. The enhanced ability of SCP2- strains, compared with $\mathrm{SCP}_{2}{ }^{+}$strains, to receive SCP2* (and presumably SCP2) probably reflects the existence of an SCP2-determined 'entry disadvantage' system (a collective term describing effects such as surface exclusion and incompatibility properties which are hard to separate experimentally in the mycelial streptomycetes: Kirby, 1976). The fact that the $\mathrm{SCP} 2^{-}$parent in $\mathrm{SCP} 2^{+} \times \mathrm{SCP}^{-}$or $\mathrm{SCP}^{*} \times \mathrm{SCP}^{-}$crosses is completely converted to $\mathrm{SCP} 2^{+}$or $\mathrm{SCP} 2^{*}$ suggests that the whole of the mixed populations participate in the matings. The failure to observe a $50 \%$ reassortment of SCP 2 and SCP2* in SCP2 ${ }^{+} \times \mathrm{SCP} 2 *$ crosses, which would be expected on the hypothesis that each spore contains a single copy of the plasmid, with segregation of related plasmids prior to or upon sporulation, is therefore significant and would be a consequence of the entry disadvantage system. Perhaps SCP1 acts to reduce the effects of this system, producing a detectable rise in the transfer frequency of $\mathrm{SCP} 2^{*}$ into $\mathrm{SCP} 2^{+}$strains carrying SCP1. Such an effect may also explain the enhancement of SCP2*-determined lethal zygosis observed on transfer of SCP2* to an SCP1-containing lawn (Fig. 1). It may also account for an apparent increase in stability of SCP2* in the presence of SCP1, by facilitating the reinfection of an SCP2- mycelial compartment by SCP2* prior to sporulation. The occurrence of the high frequency transfer phenomenon (Table 5) indicates that, under normal circumstances, the genes involved in transfer of the plasmids are not fully expressed and implies the existence of a regulatory mechanism for their control. The available data suggest that SCP2* is a derivative of SCP2 which has acquired enhanced transfer properties, perhaps due to partial derepression of the transfer genes.

SCP2 and SCP2* are able to increase the level of chromosomal recombination which occurs in matings of $S$. coelicolor A3(2). The manner in which these plasmids promote recombination is not understood since there is no evidence to suggest that any physical interaction occurs between SCP2 (or SCP2*) and the chromosome, as it does in the case of SCP1 (Hopwood \& Wright, 1976). This follows from the failure to observe an effect on the pattern of inheritance of markers clearly attributable to SCP2 or SCP2* in the present work and from the failure to identify any SCP2-primes or cases of stable integration of SCP2 into the chromosome by J. A. Ewing (personal communication). Transfer of the plasmids and chromosomal recombination appear, however, to be related, as indicated by three findings. (1) The level of recombination in $\mathrm{SCP} 2^{+} \times \mathrm{SCP}_{2}{ }^{+}$was tenfold lower than in $\mathrm{SCP}_{2}{ }^{+} \times$ $\mathrm{SCP} 2^{-}$crosses, and that in $\mathrm{SCP} 2^{*} \times \mathrm{SCP}^{+}$was about 100 times lower than in $\mathrm{SCP} 2^{*} \times$ SCP2 ${ }^{-}$crosses, reflecting the entry disadvantage seen in studies of plasmid transfer. (2) Whereas the frequency of transfer of SCP2* into an SCP2 $2^{+}$strain (in the absence of SCP1) was in the region of $10 \%$, over $90 \%$ of recombinants from such a cross inherited SCP2* rather than SCP2. (3) Variants of SCP2 with similar properties to SCP2* could be obtained by screening recombinants for enhanced fertility, a procedure which has been adopted in 
other species to obtain plasmid variants with an increased capacity to promote chromosomal recombination (Holloway, 1979).

Associated with plasmid transfer is the property of lethal zygosis which is analogous to the phenomenon of the same name which has been studied in E. coli (Skurray \& Reeves, 1973). Lethal zygosis appears to be a characteristic of many Streptomyces plasmids and has proved useful in the isolation of plasmid-negative derivatives (this paper), in the development of a plasmid transformation system for these organisms (Bibb et al., 1978), and in detecting low frequency interspecific plasmid transfer (this paper, and Hopwood \& Wright, 1973). Lethal zygosis has also led to the detection of otherwise cryptic plasmids in $S$. lividans and $S$. coelicolor (Bibb et al., 1980a, 1981).

SCP2* can be transferred from $S$. coelicolor A3(2) to at least two other strains, $S$. parvulus ATCC 12434 and $S$. lividans 66 (the latter is probably best regarded, together with $S$. coelicolor A3(2), as a member of the ' $S$. violaceoruber' species group), whereupon it undergoes stable replication and maintenance. This property may be of value in any subsequent attempts to use SCP2* or its derivatives to transfer genes between different antibiotic-producing streptomycetes, either by conjugation or transformation, in an effort to manipulate the antibiotic biosynthetic pathways of these organisms even though results so far obtained suggest that SCP2* probably has a rather narrow host-range within the genus Streptomyces at least when assessed by matings. [In matings of $S$. coelicolor containing an SCP2* derivative carrying methylenomycin resistance (Bibb et al., 1980 b) with streptomycetes belonging to 10 other species, no transfer of methylenomycin resistance could be detected (D. A. Hopwood \& H. M. Wright, unpublished results).] SCP2* has already been used as a DNA cloning vector within $S$. coelicolor, $S$. lividans and $S$. parvulus (Bibb et al., $1980 \mathrm{~b}$; Thompson et al., 1980).

Recent studies have indicated that all of the properties presently associated with SCP2* (replication, transfer, chromosomal fertility and lethal zygosis) are located in the $14.9 \mathrm{~kb}$ region between the EcoRI and the Pst I site anticlockwise of it, while a function(s) apparently affecting plasmid stability may occur outside this region (Bibb et al., 1980 b). Attempts to identify other SCP2- or SCP2*-determined properties, including heavy metal ion tolerance, u.v. resistance, antibiotic resistance, bacteriocin production and phage sensitivity, failed. [The finding of some inhibitory effect of one S. coelicolor A3(2) strain on another in the present work, independent of plasmid status, emphasizes the need to study several pairs. of isogenic strains with and without a particular plasmid before a firm conclusion of plasmid control of antibiotic or bacteriocin production can be drawn from studies such as those of Troost et al. (1979), who suggested that SCP2 determines the production of one small molecular weight antibiotic and two bacteriocins.]

These Streptomyces plasmids have characteristics which appear to be analogous to some of those exhibited by the intensively studied extrachromosomal elements of Gram-negative eubacteria such as $E$. coli but these resemblances may turn out to be superficial as a more detailed physical and functional analysis of SCP2 is carried out. For example, the apparent self-transmissibility of the $14.9 \mathrm{~kb}$ reduced replicon referred to above must surely have a different basis from that of the larger conjugative plasmids of Gram-negative bacteria. Such interesting comparative questions are now under study in this laboratory.

We thank Keith Chater for valuable discussions of this work and the manuscript.

\section{REFERENCES}

Bibi, M. J., Freeman, R. F. \& Hopwood, D. A. (1977). Physical and genetical characterisation of a second sex factor. SCP2, for Streptomices coelicolor A3(2). Molecular and General Genetics 154, 155-166.

BiBb, M. J., WARD, J. M. \& Hopwood, D. A. (1978).
Transformation of plasmid DNA into Streptomyces at high frequency. Nature, London 274, 398-400.

BisB, M. J., WARD, J. M. \& Hopwood, D. A. (1980 a). Development of a cloning system for Streptomyces. Developments in Industrial Microbiology 21, 5564. 
Bibb, M. J., Schottel, J. L. \& Cohen, S. N. (1980 b). A DNA cloning system for interspecies gene transfer in antibiotic-producing Streptomyces. Nature, London 284, 526-531.

Bibb, M. J., W ARd, J. M., Kieser, T., Cohen, S. N. \& Hopwood, D. A. (1981). Excision of chromosomal DNA sequences from Streptomyces coelicolor forms a novel family of plasmids detectable in Streptomyces lividans. Molecular and General Genetics (in the Press).

Chater, K. F. (1979). Some recent developments in Streptomyces genetics. In Genetics of Industrial Microorganisms, pp. 123-133. Edited by O. K. Sebek \& A. I. Laskin. Washington, D.C.: American Society for Microbiology.

Freeman, R. F., Bibb, M. J. \& Hopwood, D. A. (1977). Chloramphenicol acetyltransferase-independent chloramphenicol resistance in Streptomyces coelicolor A3(2). Journal of General Microbiology 98, 453-465.

Friend, E. J., Warren, M. \& Hopwood, D. A. (1978). Genetic evidence for a plasmid controlling fertility in an industrial strain of Streptomyces rimosus. Journal of General Microbiology 106, 201-206.

HAROLd, R. J. \& Hopwood, D. A. (1970). Ultravioletsensitive mutants of Streptomyces coelicolor. I. Phenotypic characterisation. Mutation Research 10, 427-438.

Holloway, B. W. (1979). Plasmids that mobilize bacterial chromosomes. Plasmid 2, 1-19.

Hopwood, D. A. (1967). Genetic analysis and genome structure in Streptomyces coelicolor. Bacteriological Reviews 31, 373-403.

Hopwood, D. A. (1978). Extrachromosomally determined antibiotic production. Annual Review of Microbiology 32, 373-392.

Hopwood, D. A. (1979). Genetics of antibiotic production by actinomycetes. Journal of Natural Products 42, 596-602.

Hopwood, D. A. \& WRight, H. M. (1973). Transfer of a plasmid between Streptomyces species. Journal of General Microbiology 77, 187-195.

Hopwood, D. A. \& WRight, H. M. (1976). Interactions of the plasmid SCP1 with the chromosome of Streptomyces coelicolor A3(2). In Second International Symposium on the Genetics of Industrial Microorganisms, pp. 607-619. Edited by K. D. Macdonald. London: Academic Press.

Hopwood, D. A., Harold, R. J., Vivian, A. \& Ferguson, H. M. (1969). A new kind of fertility variant in Streptomyces coelicolor. Genetics $\mathbf{6 2}$, 461-477.

Hopwood, D. A., Chater, K. F., Dowding, J. E. \& Vivian, A. (1973). Advances in Streptomyces coelicolor genetics. Bacteriological Reviews 37, 371-405.

Hopwood, D. A., BiBB, M. J., WARD, J. M. \& WestPheling, J. (1979). Plasmids in Streptomyces coelicolor and related species. In Plasmids of Medical, Environmental and Commercial Importance, pp. 245-258. Edited by K. N. Timmis \& A. Pühler. Amsterdam: Elsevier-North Holland.

KIRBY, R. (1976). Genetic studies on Streptomyces coelicolor plasmid one. Ph.D. thesis, University of East Anglia, Norwich, U.K.
Kirby, R. \& Hopwood, D. A. (1977). Genetic determination of methylenomycin synthesis by the SCP1 plasmid of Streptomyces coelicolor A3(2). Journal of General Microbiology 98, 239-252.

Lomovskaya, N. D., MKrtumian, N. M., Gostimskaya, N. L. \& Danilenko, V. N. (1972). Characterization of temperate actinophage $\phi \mathrm{C} 31$ isolated from Streptomyces coelicolor A3(2). Journal of Virology 9, 258-262.

OKANISHI, M. (1979). Plasmids and antibiotic synthesis in streptomycetes. In Genetics of Industrial Microorganisms, pp. 134-140. Edited by O. K. Sebek \& A. I. Laskin. Washington, D.C.: American Society for Microbiology.

Okanishi, M., Suzuki, K. \& Umezawa, H. (1974). Formation and reversion of streptomycete protoplasts: cultural conditions and morphological study. Journal of General Microbiology 80, 389-400.

SCHREMPF, H. \& Goebel, W. (1977). Characterization of a plasmid from Streptomyces coelicolor A3(2). Journal of Bacteriology 131, 251-258.

SchrempF, H. \& Goebel, W. (1979). Functions of plasmid genes in Streptomyces reticuli. In Plasmids of Medical, Environmental and Commercial Importance, pp. 259-268. Edited by K. N. Timmis \& A. Pühler. Amsterdam: Elsevier-North Holland.

SCHREMPF, H., BuJARD, H., HopwOOD, $\bar{D}$. A. \& GoEBEL, W. (1975). Isolation of covalently closed circular deoxyribonucleic acid from Streptomyces coelicolor. Journal of Bacteriology 121, 416-421.

Skurray, R. A. \& Reeves, P. (1973). Characterization of lethal zygosis associated with conjugation in Escherichia coli K-12. Journal of Bacteriology 113, 58-70.

Southern, E. M. (1975). Detection of specific sequences among DNA fragments separated by gel electrophoresis. Journal of Molecular Biology 98, 503-517.

Stocker, B. A. D., Smith, S. M. \& Ozeki, H. (1963). High infectivity of Salmonella typhimurium newly infected by the ColI factor. Journal of General Microbiology 30, 201-221.

Thompson, C. J., Ward, J. M. \& Hopwood, D. A. (1980). DNA cloning in Streptomyces: resistance genes from antibiotic-producing species. Nature, London 286, 525-527.

Troost, T. R., Danilenko, V. N. \& Lomovskaya, N. D. (1979). Fertility properties and regulation of antimicrobial substance production by plasmid SCP2 of Streptomyces coelicolor. Journal of Bacteriology 140, 359-368.

ViviaN, A. (1971). Genetic control of fertility in Streptomyces coelicolor A3(2): plasmid involvement in the interconversion of UF and IF strains. Journal of General Microbiology 69, 353-364.

Vivian, A. \& Hopwood, D. A. (1970). Genetic control of fertility in Streptomyces coelicolor A3(2): the IF fertility type. Journal of General Microbiology 64, 101-117.

WestPheling, J. (1980). Physical studies of Streptomyces plasmids. Ph.D. thesis, University of East Anglia, Norwich, U.K.

WRIGHT, L. F. \& Hopwood, D. A. (1976). Identification of the antibiotic determined by the SCP1 plasmid of Streptomyces coelicolor A3(2). Journal of General Microbiology 95, 96-106. 